\title{
Seroprevalence of Leptospira spp. infection in sheep from northwest of Rio Grande do Sul, Brazil
}

\author{
Angélica Consalter ${ }^{1 *}$ Eraldo Lourenso Zanella ${ }^{2}$ Gabriel Mendes de Souza Martins ${ }^{3}$ \\ Hugo Libonati de Araujo ${ }^{1}$ Walter Lilenbaum ${ }^{3}$ Guilherme Nunes de Souza ${ }^{4}$ (D) Ana Maria Reis Ferreira ${ }^{5}$
}

${ }^{1}$ Programa de Pós-graduação em Clínica e Reprodução Animal, Universidade Federal Fluminense (UFF), 24230340, Niterói, RJ, Brasil. E-mail: angelicaonsalter@hotmail.com. *Corresponding author.

${ }^{2}$ Laboratório de Reprodução e Melhoramento Genético Animal, Universidade de Passo Fundo (UPF), Passo Fundo, RS, Brasil.

${ }^{3}$ Laboratório de Bacteriologia Veterinária, Universidade Federal Fluminense (UFF), Niterói, RJ, Brasil.

${ }^{4}$ Embrapa Gado de Leite, Juiz de Fora, MG, Brasil.

${ }^{5}$ Departamento de Patologia e Clínica Veterinária, Universidade Federal Fluminense (UFF), Niterói, RJ, Brasil.

ABSTRACT: Leptospirosis is a zoonosis that is widely distributed in tropical countries. This infection is also associated with reproductive losses in livestock, which has a significant economic impact. The objective of this study is to investigate the seroprevalence and risk factors associated with leptospiral infection in commercial sheep flocks from the northwestern mesoregion of Rio Grande do Sul. Serum samples were analyzed in 319 sheep using the Microscopic Agglutination Test (MAT). At the time of sampling, an individual and herd questionnaire was carried out to investigate the risk factors. On an individual level, positive reactions were observed in 5.6\% (18/319) of the studied sera, with Sejroe being the most prevalent serogroup. Animals $>3$ years old were more likely to be seropositive than animals 1-3 years old (OR 14.4; $95 \%$ CI 1.9-110). The predominance of Sejroe serogroup in this manner draws attention to how subclinical infection is associated with economic losses. Therefore, the importance of maintaining measures for the prevention and control of leptospirosis among the sheep flocks of the studied region is reiterated.

Key words: Leptospira spp., sheep, MAT, seroprevalence.

Soroprevalência da infecção por Leptospira spp. em ovinos do noroeste do Rio Grande do Sul, Brasil

RESUMO: A leptospirose é uma zoonose amplamente distribuída em países tropicais. Essa infecção também está associada a perdas reprodutivas na pecuária, apresentando uma relevância econômica notável. O objetivo deste estudo foi investigar a soroprevalência e os fatores de risco associados à infecção por leptospirose em rebanhos comerciais de ovinos da mesorregião noroeste do Rio Grande do Sul. Amostras de soro de 319 ovelhas foram analisadas pelo Teste de Aglutinação Microscópica (MAT). No momento da amostragem foi realizado um questionário individual e de rebanho para investigar os fatores de risco. No nível individual, reações positivas foram observadas em $5.6 \%$ (18/319) dos soros estudados, sendo Sejroe o sorogrupo mais prevalente. Animals $>3$ years old were more likely to be seropositive than animals 1-3 years old (OR 14.4; 95\% CI 1.9-110). A predominância do sorogrupo Sejroe chama a atenção para a infecção subclínica associada a perdas econômicas. Portanto, reitera-se a importância da manutenção de medidas de prevenção e controle da leptospirose entre os rebanhos ovinos da região estudada.

Palavras-chave: Leptospira spp., ovinos, MAT, soroprevalência.

\section{INTRODUCTION}

Sheep farming is one of the most important activities in Rio Grande do Sul, offering great economic potential for the region. The state is the largest producer of sheep in Brazil (IBGE, 2014), with reproductive efficiency being the basis of profitability in sheep flocks (FTHENAKIS et al., 2015). However, there are several challenges for the maintenance of reproductive efficiency, with handling infectious diseases being key among them. Leptospirosis is a significant zoonotic bacterial disease (ALLAN et al., 2018; COSTA et al., 2015), which has been associated with reproductive failure and economic losses in sheep (RIDLER et al., 2015).

$$
\text { Leptospirosis causes subclinical }
$$
infections in sheep such as infertility, an increased number of services per conception and extended 
delivery intervals, miscarriage, stillbirths, and weak lambs (MARTINS \& LILENBAUM, 2014). The seroprevalence of anti-Leptospira antibodies in sheep flocks in Brazil varies from 3\% in São Paulo (AMORIM et al., 2016) to $47.4 \%$ in Rio de Janeiro (MARTINS et al., 2012). Additionally, Sejroe is the serogroup most associated with this infection in small ruminants, causing many reproductive failures in our country (MARTINS et al., 2012; VALLÉE et al., 2018).

Leptospirosis is a neglected disease and few studies have been conducted in the state of Rio Grande do Sul, despite the great impact of the infection on the economy. In addition, there is a lack of information regarding the factors associated with such infection. Thus, this study aimed to investigate the seroprevalence and risk factors associated with leptospirosis infection in commercial sheep flocks of the northwestern mesoregion of Rio Grande do Sul.

\section{MATERIALS AND METHODS}

A cross-sectional study has been conducted using 319 serum samples from sheep collected between August to October of 2016. Samples were from 14 flocks located in 10 municipalities of the northwest mesoregion of Rio Grande do Sul (Figure 1), chosen by convenience but respecting the representative sample size distribution. To be included in this study, flocks should have at least
20 animals, being at least one adult male and one young male (1 year) and the remaining females. Serum samples were assayed by a microscopic agglutination test (MAT). The total population of sheep in the studied region was 327,828 according to the Brazilian Institute of Geography and Statistics (IBGE, 2014). Thus, the minimum representative number (n) of samples required for this study was 280 assessed considering a $22.8 \%$ of expected prevalence (RIZZO et al., 2014), 5\% error and 95\% CI using the software EpiInfo 7.1.5 (CDC, 2002). Blood samples were collected by venipuncture of the jugular vein in $10 \mathrm{~mL}$ tubes (Vacutainer ${ }^{\circledR}$ ) without anticoagulant, then conditioned in an isothermal container at $5{ }^{\circ} \mathrm{C}$, centrifugated at $1,000 \mathrm{xg}$ for $10 \mathrm{~min}$ and sera were conditioned in microtubes at $-20{ }^{\circ} \mathrm{C}$.

The MAT was performed as recommended by the OIE (2008). Samples were tested for a panel of ten live antigens of Leptospira serovars (serogroups), Hardjoprajitno (Sejroe), Icterohaemorrhagiae and Copenhageni (Icterohaemorrhagiae), Autumnalis (Autumnalis), Djasiman (Djasiman), Australis (Australis), Pomona (Pomona), Hebdomadis (Hebdomadis), Grippotyphosa (Grippotyphosa) and Canicola (Canicola). This panel of strains has been structured based on previous seroprevalence information (HERRMANN et al., 2004). In addition, in order to improve the sensitivity, a local isolate of Leptospira noguchii (serogroup Autumnalis) is

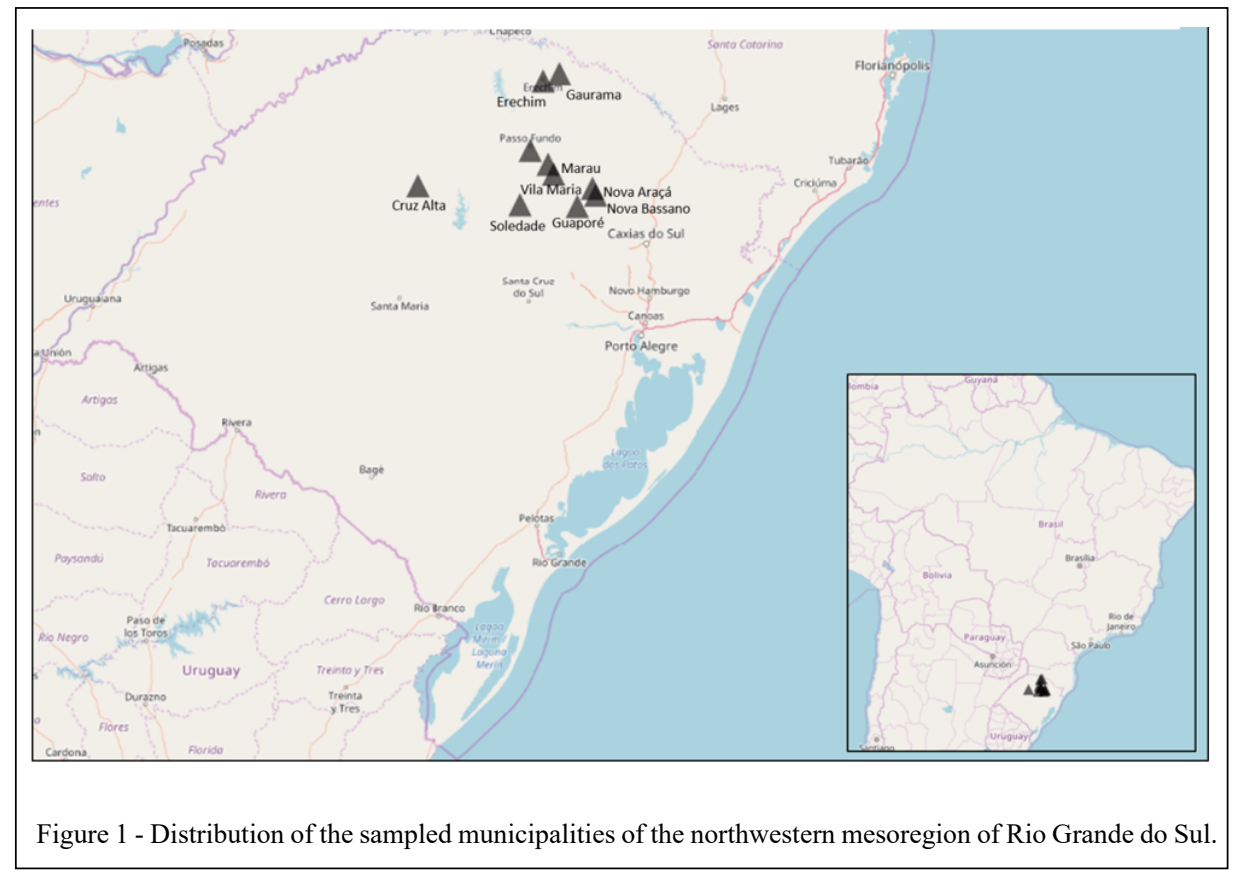

Ciência Rural, v.49, n.12, 2019. 
included in the panel. Strains were grown in liquid EMJH during 7 days at $28-30{ }^{\circ} \mathrm{C}$, evaluated under the darkfield microscopy for the absence of autoagglutination and contamination.

Serological samples were initially analyzed at a dilution of 1: 100, and those with agglutination level equal to or greater than $50 \%$ were then diluted again in a geometric ratio of two (1: 200, 1: 400 and 1: 800). Serological titration was represented to correspond with the highest dilution that presented a positive result. Animals were considered positive when titers $\geq 100$ (OIE, 2014). In the occurrence of seroreactivity for more than one serovar, the most frequent strain in the flock was considered the infective one.

At the same time, an epidemiological questionnaire, including questions regarding individual (gender, age and breed) and flock-level characteristics (type and system of production, consortium with other animals, water source, type of sheepfold, veterinary care, presence of fetal malformation and abortion in the last 12 months, presence of dogs and rodents on the farm) is used to identify the risk factors related to seroreactivity against Leptospira spp.

The independent variables or explanatory variables (obtained in the epidemiological questionnaire) were analyzed on the explanation of the biological phenomenon (a result of serological analysis). Chisquare test was used to evaluate the association between serology results and explanatory variables. All analyses were conducted under a confidence level of $95 \%$. Statistical analyses were performed in SPSS version 8.0 (SPSS, 1998). SPSS. 1998. Statistical Package for the Social Science. SPSS Inc., Chicago, IL.

\section{RESULTS}

A total of $5.6 \%$ (18/319), 95\% CI (3.4-8.8), animals were reactive by MAT. The most prevalent serogroups were Sejroe $33.3 \%(6 / 18)$, Djasiman $27.7 \%(5 / 18)$ and Grippotyphosa $22.2 \%(4 / 18)$. Titers of 100 were the most commonly observed $(72.2 \%)$ followed by $200(22.2 \%)$ and $400(5.5 \%)$. Animals $>3$ years old were more likely to be seropositive than animals 1-3 years old (OR 14.4; 95\% CI 1.9-110) (Table 1). The seroactivity of the animals in the herds is presented in table 2 .

\section{DISCUSSION}

Seroreactivity against Leptospira interrogans was observed in $5.6 \%$ of the samples analyzed. For more than a decade, HERMANN et al. (2004) observed a prevalence higher than that observed in our study, describing $34.26 \%$ of reactive animals in southeast and southwest mesoregions of the same state. This study was carried out in another region and in a different research period (January to March), which makes it difficult to compare. This period is characterized by higher temperatures when compared to our study, conducted between August and October, which had a minimum temperature of $10^{\circ} \mathrm{C}$ and a maximum of $21^{\circ} \mathrm{C}$ in August (INMET, 2016). Leptospires has an optimum growth temperature of 28-30 $30^{\circ} \mathrm{C}$ (ADLER \& DE LA PEÑA MOCTEZUMA, 2010) and temperatures below $24^{\circ} \mathrm{C}$ hinder bacterial proliferation. So, we have hazarded that the low prevalence verified in our study can be related to a climate differences, region and a possible better preventive management currently employed in sheep herds.

In other regions of Brazil, the general average is $20-30 \%$ (CARVALHO et al., 2014; RIZZO et al., 2014). Overall, sero-reactivity is low in this study and similar results were reported in the centralwestern region of the state of São Paulo, where 3\% of the sheep were seropositive for Leptospira spp. (AMORIM et al., 2016) and in the northeast of Brazil, Piauí and Pernambuco State, where $4.6 \%$ of the animals were positive (DOS SANTOS et al., 2017). Recently, a low seroprevalence for leptospirosis was reported in cattle in the western part of the state of Santa Catarina, a region near the northwest of Rio Grande do Sul (FÁVERO et al., 2017).

Conversely, higher prevalence rates of Leptospira spp. were observed in Rio de Janeiro, where leptospirosis was described as the main infectious problem, representing $47.4 \%$ of the sheep sampled and the researchers concluded that this may contribute to the decrease in the productivity of small ruminants (MARTINS et al., 2012). Variation in results indicated that herd management conditions and, animal density, as well as the climatic conditions reported in southeastern Brazil, contribute to the spread of the disease.

High seropositivity to Leptospira has also been often associated with exposure to environmental risk factors, such as rainfall and flooding. According to CORREIA et al. (2017), an increase in the prevalence of Leptospira spp. infections in cattle is related to an enhancement in precipitation rates; however, the infections associated with adapted serogroups were not affected by environmental conditions. In this study, although the collections were performed during times of greater precipitation in Rio Grande do Sul, the temperature was low so does not favor the survival of the bacterium, meaning they did not happen with a high prevalence of leptospirosis or acute clinical cases 
Table 1 - Chi-squared test of risk factors associated with the presence of anti-Leptospira antibodies in sheep flocks of northwestern of Rio Grande do Sul.

\begin{tabular}{|c|c|c|c|c|c|c|}
\hline \multirow[t]{3}{*}{ Variables } & \multirow[t]{3}{*}{ Categories } & \multicolumn{4}{|c|}{ Serology } & \multirow[t]{3}{*}{${ }^{*} P$} \\
\hline & & \multicolumn{2}{|c|}{ Negative } & \multicolumn{2}{|c|}{ Positive } & \\
\hline & & $\mathrm{n}$ & $\%$ & $\mathrm{n}$ & $\%$ & \\
\hline \multirow{2}{*}{ Gender } & Male & 57 & 96.6 & 2 & 3.4 & \multirow{2}{*}{0.534} \\
\hline & Female & 244 & 93.8 & 16 & 6.2 & \\
\hline \multirow{2}{*}{ Age } & 1 a 3 & 138 & 99.3 & 1 & 0.7 & \multirow{2}{*}{$<0.00$} \\
\hline & $>3$ & 163 & 90.6 & 17 & 9.4 & \\
\hline \multirow[t]{2}{*}{ Breed } & $\begin{array}{c}\text { (Dorper, Lacaune, Poll Dorset, Suffolk, Mixed } \\
\text { Breed) }\end{array}$ & 110 & 94.0 & 7 & 6.0 & \multirow[t]{2}{*}{0.841} \\
\hline & Texel & 191 & 94.6 & 11 & 5.4 & \\
\hline \multirow{3}{*}{ Production objective } & Meat & 117 & 94.4 & 7 & 5.6 & \multirow{3}{*}{0.469} \\
\hline & Mixed & 47 & 97.9 & 1 & 2.1 & \\
\hline & Genetics & 137 & 93.2 & 10 & 6.8 & \\
\hline \multirow{2}{*}{ Production system } & Intensive & 24 & 100.0 & 0 & 0.0 & \multirow{2}{*}{0.213} \\
\hline & Semi-intensive & 277 & 93.9 & 18 & 6.1 & \\
\hline \multirow{2}{*}{ Consortium with other animals } & Yes & 141 & 95.3 & 7 & 4.7 & \multirow{2}{*}{0.511} \\
\hline & No & 160 & 93.6 & 11 & 6.4 & \\
\hline \multirow{4}{*}{ Source of water } & Weir & 50 & 92.6 & 4 & 7.4 & \multirow{4}{*}{0.326} \\
\hline & Cistern & 20 & 100.0 & 0 & 0.0 & \\
\hline & Artesian well & 121 & 92.4 & 10 & 7.6 & \\
\hline & Mixed & 110 & 96.5 & 4 & 3.5 & \\
\hline \multirow{3}{*}{ Type of sheepfold } & Suspended & 122 & 91.7 & 11 & 8.3 & \multirow{3}{*}{0.158} \\
\hline & Ground floor & 155 & 95.7 & 7 & 4.3 & \\
\hline & Absent & 24 & 100.0 & 0 & 0.0 & \\
\hline \multirow{2}{*}{ Veterinary care } & Yes & 281 & 94.0 & 18 & 6.0 & \multirow{2}{*}{0.615} \\
\hline & No & 20 & 100.0 & 0 & 0.0 & \\
\hline \multirow{2}{*}{ Presence of dogs } & Yes & 282 & 94.3 & 17 & 5.7 & \multirow{2}{*}{1.000} \\
\hline & No & 19 & 95.0 & 1 & 5.0 & \\
\hline \multirow{2}{*}{ Presence of rodents } & Yes & 280 & 94.0 & 18 & 6.0 & \multirow{2}{*}{0.619} \\
\hline & No & 21 & 100.0 & 0 & 0.0 & \\
\hline \multirow{2}{*}{ Fetal malformation } & Yes & 39 & 97.5 & 1 & 2.5 & 0.482 \\
\hline & No & 213 & 93.0 & 16 & 7.0 & 0.482 \\
\hline Shortion in the loct 12 monthe & Yes & 161 & 95.8 & 7 & 4.2 & 0228 \\
\hline Abortion in the last 12 months & No & 140 & 92.7 & 11 & 7.3 & 0.228 \\
\hline
\end{tabular}

diagnosed in the sampled sheep. In this study a limitation was the use of a convenience sample, as formal random sampling was not possible. Thus, data analysis should ideally consider the cluster sampling design.

The importance of the knowledge of the associated risk factors is emphasized, which allows for a more appropriate view of the leptospirosis in the locality, with better defined control perspectives. In sheep production systems the presence of dogs, rodents and wild animals, as well as animal consortiums have been considered important factors in the epidemiology of leptospirosis (CAMPOS et al., 2017). Dogs and rodents were present in all farms, which made it impossible to assess the influence of their presence inside the farms and might prove to be a bias in this study. Animals at three or more years old proved to be a significant observed variable, which agreed with other studies (DOS SANTOS et al., 2017) and is related to the longer exposure to bacteria.

No statistical significance was observed for the abortion in sheep in the studied herds. The questionnaire answered by the producers may contain a bias regarding reproductive data, fetal malformation, and abortion in the last 12 months, since the tabulation of this data on the property is often absent or inadequate, making it difficult to report the period in which the changes occurred. According to CHOI \& PAK, (2004), failure to identify a common starting time for exposure

Ciência Rural, v.49, n.12, 2019. 
Table 2 - Sero-prevalence of Leptospira spp in sheep from northwestern Rio Grande do Sul State, Brazil.

\begin{tabular}{|c|c|c|c|c|c|}
\hline Municipality & Flock ID & $\mathrm{N}$ & Seroreactive (\%) & Range of titres & Predominant serogroup \\
\hline Passo Fundo & 1 & 30 & 0 & - & - \\
\hline Vila Maria & 2 & 30 & $4(13.3)$ & $100-400$ & Sejroe \\
\hline Marau & 3 & 21 & 0 & - & - \\
\hline Nova Araça & 4 & 20 & $1(5)$ & 800 & Sejroe \\
\hline Nova Bassano & 5 & 20 & $1(5)$ & 100 & Grippotyphosa \\
\hline Soledade & 6 & 24 & 0 & - & - \\
\hline Guaporé & 7 & & 0 & - & - \\
\hline Erechim & 8 & 23 & $2(8.7)$ & 100 & Grippotyphosa \\
\hline Erechim & 9 & 20 & $3(15)$ & 100 & Grippotyphosa \\
\hline Gaurama & 10 & 20 & $5(40)$ & $100-200$ & Sejroe \\
\hline Erechim & 11 & 20 & $1(5)$ & 100 & Grippotyphosa \\
\hline Cruz Alta & 12 & 27 & $1(3.7)$ & 100 & Icterohaemorrhagiae \\
\hline Passo Fundo & 13 & 20 & 0 & - & - \\
\hline Soledade & 14 & 21 & 0 & - & - \\
\hline Total & & 319 & $18(5.6)$ & $100-800$ & Sejroe \\
\hline
\end{tabular}

or illness may lead to bias. Although, the outbreaks of leptospirosis have attracted more attention, the silent, endemic and chronic disease is important because it causes constant economic damage (MARTINS \& LILENBAUM, 2014). Among these losses, estrus repetition was strongly associated with leptospirosis and the serogroup Sejroe was predominant in (LIBONATI et al., 2018). This might be related to the absence of a significant level of abortion in our study. Despite the presence of the serogroup Sejroe, reproductive failure was not considered a factor associated with leptospirosis in those flocks. In order to recognize subclinical leptospirosis, it is necessary to monitor the management and to look more critically at reproductive failures in the herds.

\section{CONCLUSION}

In this study, the seroprevalence for leptospirosis in sheep was low and animals $>3$ years old were more likely to be seropositive than animals 1-3 years old. Predominance of Sejroe serogroup draws attention to the subclinical infection associated with economic losses. Therefore, the importance of the maintenance of measures for prevention and control of leptospirosis among the sheep flocks of the studied region is reiterated.

\section{ACKNOWLEDGEMENTS}

The authors thank the veterinarians who helped in the field Rogério Nadal and Paulo Michelon. This study was financed in part by the Coordenação de Aperfeiçoamento de Pessoal de
Nível Superior - Brasil (CAPES) - Finance Code 001 and FAPERJFundação de Amparo à Pesquisa do Estado do Rio de Janeiro.

\section{BIOETHICS AND \\ COMMITTEE APPROVAL}

BIOSECURITY

The Animal Ethics Committee of the Federal Fluminense University approved this study under the protocol 832 and the Animal Ethics Committee of Universidade de Passo Fundo, RS, Brazil under the protocol number 035 .

\section{DECLARATION OF CONFLICT OF INTERESTS}

The authors declare that they have no conflict of interest. The authors are responsible for the content and writing of the paper.

\section{AUTHORS' CONTRIBUTIONS}

Angélica Consalter and Eraldo Lourenso Zanella conceived, designed and performed experiments. Angélica Consalter, Gabriel Mendes de Souza Martins and Hugo Libonati de Araujo carried out the lab analyses. Ana Maria Reis Ferreira and Walter Lilenbaum supervised and coordinated the animal experiments and provided clinical data. Guilherme Nunes de Souza performed statistical analyses of experimental data. All authors critically revised the manuscript and approved of the final version.

\section{REFERENCES}

ADLER, B.; DE LA PEÑA MOCTEZUMA, A. Leptospira and leptospirosis. Veterinary Microbiology, v.140, n.3-4, p.287-296, 2010. Available from: <http://www.sciencedirect.com/science/ article/pii/S0378113509001163>. Accessed: Jul. 16, 2018. doi: 10.1016/j.vetmic.2009.03.012. 
ALLAN, K. J. et al. Assessment of animal hosts of pathogenic Leptospira in northern Tanzania. PLoS neglected tropical diseases, v.12, n.6, p.e0006444, 2018. Available from: <https:// www.ncbi.nlm.nih.gov/pubmed/29879104>. Accessed: Jul. 07, 2018. doi: 10.1371/journal.pntd.0006444.

AMORIM, R. M. et al. Soroprevalência da leptospirose em ovinos da região centro-oeste do estado de São Paulo. Veterinária e Zootecnia, v.23, n.2, p.294-305, 2016. Available from: <https:// scholar.google.com.br>. Accessed: Jan. 03, 2018.

CAMPOS, Â. P. et al. Seroprevalence and risk factors for leptospirosis in cattle, sheep, and goats at consorted rearing from the State of Piauí, northeastern Brazil. Tropical Animal Health and Production, v.49, n.5, p.899-907, 2017. Available from: <http:// link.springer.com/10.1007/s11250-017-1255-2>. Accessed: Jan. 09, 2018. doi: $10.1007 / \mathrm{s} 11250-017-1255-2$.

CARVALHO, S. M. DE et al. Leptospirosis seroprevalence and risk factors for sheep in Maranhão state, Brazil. Tropical Animal Health and Production, v.46, n.2, p.491-494, 2014. Available from: <https://link.springer.com/article/10.1007/s11250-013-05051>. Accessed: Jan. 15, 2018. doi: 10.1007/s11250-013-0505-1.

CDC. (Centers for Disease Control and Prevention). EpiInfo 7.1.5. 2002. Available from: $<$ https://wwwn.cdc.gov/epiinfo/html/ downloads.htm>. Accessed: Jan. 15, 2018.

CHOI, B. C. K.; PAK, A. W. P. A Catalog of Biases in Questionnaires. Preventing Chronic Disease, v.2, n.1, 2004 Available from: <https://www.ncbi.nlm.nih.gov/pmc/articles/ PMC1323316/>. Accessed: May, 14, 2019.

CORREIA, L.; LOUREIRO, A. P.; LILENBAUM, W. Effects of rainfall on incidental and host-maintained leptospiral infections in cattle in a tropical region. The Veterinary Journal, v.220, p.63-64, 2017. Available from: <https://www.ncbi.nlm.nih.gov/pubmed/28190497>. Accessed: Jan. 01, 2018. doi: 10.1016/j.tvj1.2016.12.016.

COSTA, F. et al. Global Morbidity and Mortality of Leptospirosis: A Systematic Review. PLOS Neglected Tropical Diseases, v.9, n.9, p.e0003898, 2015. Available from: <http://journals.plos.org/ plosntds/article?id=10.1371/journal.pntd.0003898>. Accessed: Jul. 02, 2018. doi: 10.1371/journal.pntd.0003898.

DOS SANTOS, L. F. et al. Seroepidemiological survey on Leptospira spp. infection in wild and domestic mammals in two distinct areas of the semi-arid region of northeastern Brazil. Tropical Animal Health and Production, v.49, n.8, p.1715-1722, 2017. Available from: $<$ http://link.springer.com/10.1007/s11250-017-1382-9>. Accessed: Jan. 10, 2018. doi: 10.1007/s11250-017-1382-9

FÁVERO, J. F. et al. Bovine leptospirosis: Prevalence, associated risk factors for infection and their cause-effect relation. Microbial Pathogenesis, v.107, p.149-154, 2017. Available from: <http:// linkinghub.elsevier.com/retrieve/pii/S0882401017301791>. Accessed: Jan. 03, 2018. doi: 10.1016/j.micpath.2017.03.032.

FTHENAKIS, G. C. et al. Interactions between parasitic infections and reproductive efficiency in sheep. Veterinary Parasitology, v.208, n.1-2, p.56-66, Fev. 2015. Available from: <http:// linkinghub.elsevier.com/retrieve/pii/S0304401714006517>. Accessed: Jan. 03, 2018. doi: 10.1016/j.vetpar.2014.12.017.
HERRMANN, G. P. et al. Soroprevalência de aglutininas antiLeptospira spp. em ovinos nas Mesorregiões Sudeste e Sudoeste do Estado Rio Grande do Sul, Brasil. Ciência Rural, v.34, n.2, 2004. Available from: $<$ http://www.scielo.br/scielo.php?pid=S010 $384782004000200017 \&$ script $=$ sci_abstract\&tlng=pt $>$. Accessed: Jan. 03, 2018. doi: 10.1590/S0103-84782004000200017.

IBGE- (INSTITUTO BRASILEIRO DE GEOGRAFIA E ESTATÍSTICA). Municipal Liverstock Research. 2014. Available from: <www.sidra.ibge.gov.br>. Accessed: Dec. 15, 2017.

INMET- (INSTITUTO NACIONAL DE METEREOLOGIA). Boletins Climáticos para o Rio Grande do Sul. 2016. Available from: <http://www.inmet.gov.br/portal/arq/clima/prog_clima_rs/ bol_ago2016.pdf>. Accessed: May, 25, 2019.

LIBONATI, H. A. et al. Leptospirosis is strongly associated to estrus repetition on cattle. Tropical Animal Health and Production, 2 maio 2018. Available from: <https://doi.org/10.1007/s11250-018-1604-9>. Accessed: Aug. 20, 2018. doi: 10.1007/s11250-018-1604-9.

MARTINS, G. et al. Leptospirosis as the most frequent infectious disease impairing productivity in small ruminants in Rio de Janeiro, Brazil. Tropical Animal Health and Production, v.44, n.4, p.773-777, abr. 2012. Available from: <http://link.springer. com/10.1007/s11250-011-9964-4>. Accessed: Jan. 03, 2018. doi: $10.1007 / \mathrm{s} 11250-011-9964-4$.

MARTINS, G.; LILENBAUM, W. Leptospirosis in sheep and goats under tropical conditions. Tropical Animal Health and Production, v.46, n.1, p.11-17, Jan. 2014. Available from: $<$ http:// link.springer.com/10.1007/s11250-013-0480-6>. Accessed: Jan. 09, 2018. doi: 10.1007/s11250-013-0480-6.

OIE. (Manual of Diagnostic Tests and Vaccines for Terrestrial Animals, World Organisation for Animal Health). 2008. Available from: <https://www.oie.int/doc/ged/D12008.PDF>. Accessed: Aug. 20, 2018.

OIE. (Manual of Diagnostic Tests and Vaccines for Terrestrial Animals, World Organisation for Animal Health). 2014. Available from: <http://www.oie.int/standard-setting/terrestrialmanual/access-online/>. Accessed: Aug. 20, 2018.

RIDLER, A. et al. Factors associated with fetal losses in ewe lambs on a New Zealand sheep farm. New Zealand Veterinary Journal, v.63, n.6, p.330-334, 2 Nov. 2015. Available from: $<$ https://www. ncbi.nlm.nih.gov/pubmed/25980526>. Accessed: Jan. 01, 2018. doi: $10.1080 / 00480169.2015 .1037813$

RIZZO, H. et al. Soropositividade para leptospirose e desempenho reprodutivo de ovinos de criatórios localizados no estado de São Paulo, Brasil. Revista Brasileira de Medicina Veterinária, v.36, p.244-250, 2014. Available from: <https://bdpi.usp.br/single. php?_id $=002729969 \&$ locale $=e n \_U S \& l o c a l e=p t \_B R>$. Accessed: Jan. $\overline{03}, 2018$.

VALLÉE, E. et al. Effects of natural infection by L. borgpetersenii serovar Hardjo type Hardjo-bovis, L. interrogans serovar Pomona and leptospiral vaccination on sheep reproduction. Theriogenology, v.114, p.126-135, 1 Jul. 2018. Available from: <http://www. sciencedirect.com/science/article/pii/S0093691X18301067>. Accessed: Jul. 16, 2018. doi: 10.1016/j.theriogenology.2018.03.022. 